Maurer School of Law: Indiana University

10-1-2015

\title{
A Behavioral Theory of Legal Ethics
}

Andrew M. Perlman

Suffolk University Law School, aperlman@suffolk.edu

Follow this and additional works at: https://www.repository.law.indiana.edu/ilj

Part of the Legal Ethics and Professional Responsibility Commons, Legal Profession Commons, and the Social Psychology Commons

\section{Recommended Citation}

Perlman, Andrew M. (2015) "A Behavioral Theory of Legal Ethics," Indiana Law Journal: Vol. 90 : Iss. 4 , Article 6.

Available at: https://www.repository.law.indiana.edu/ilj/vol90/iss4/6

This Article is brought to you for free and open access by the Law School Journals at Digital Repository @ Maurer Law. It has been accepted for inclusion in Indiana Law Journal by an authorized editor of Digital Repository @ Maurer Law. For more information, please contact rvaughan@indiana.edu.

\section{$\Psi$}

JEROME HALL LAW LIBRARY

INDIANA UNIVERSITY

Maurer School of Law
Bloomington 


\title{
A Behavioral Theory of Legal Ethics
}

\author{
ANDREW M. PERLMAN*
}

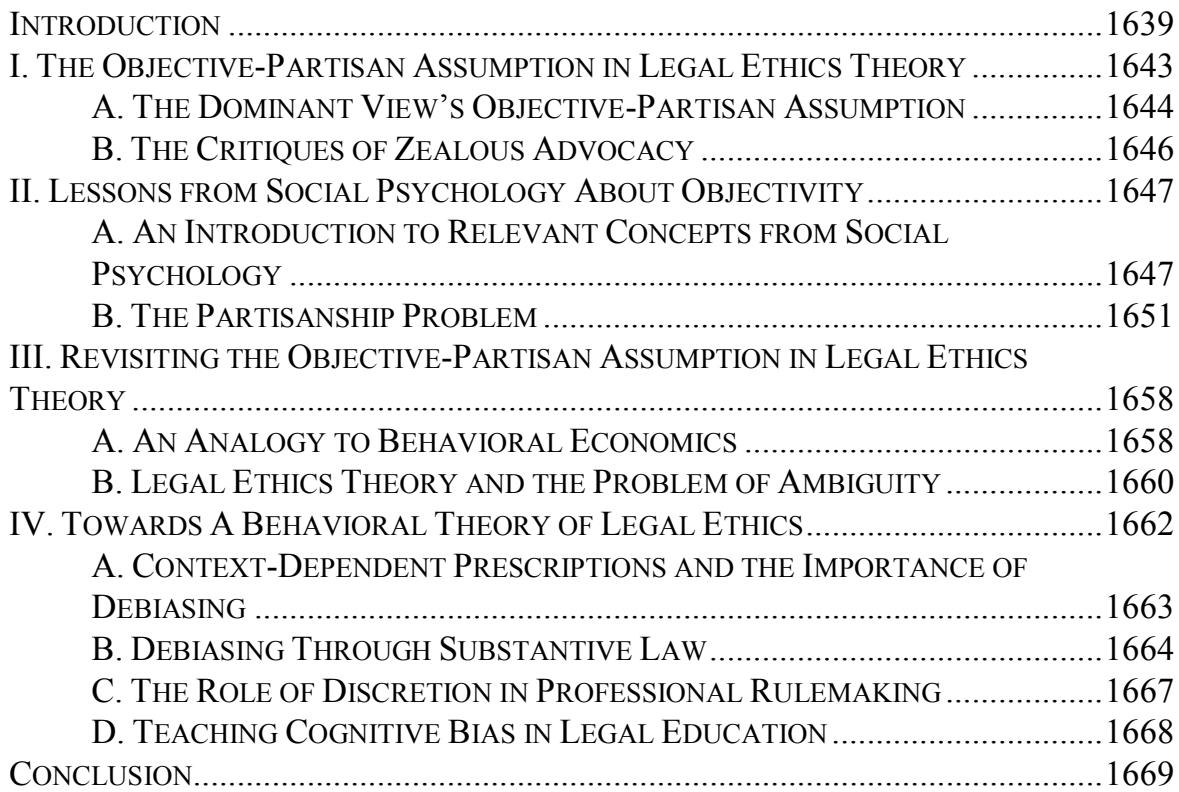

\section{INTRODUCTION}

Imagine a lawyer who discovers that a client has several smoking-gun documents that will doom the client's case if produced in discovery. Also assume the client tells the lawyer to use all lawful methods to avoid producing the information. Some legal ethicists argue that the lawyer should comply with the client's instruction and pursue every permissible tactic, that is, go right up to the line but not cross it. ${ }^{1}$ Critics of this

$\dagger$ Copyright (C) 2015 Andrew M. Perlman.

* Professor of Law, Suffolk University Law School. B.A., Yale College; J.D., Harvard Law School; LL.M., Columbia Law School. I am grateful to several friends and colleagues who gave me valuable feedback on early drafts of this Article, including Tigran Eldred, Russell Gold, Bruce Green, Jan Jacobowitz, David McGowan, Mark Rogerson, Patrick Shin, Joshua Silverstein, Keith Swisher, and Bradley Wendel. I also benefited a great deal from the assistance of research librarian Ellen Delaney and law students Dahlia Ali, Nicole Annmarie Faille, Cody Friesz, Jared Heit, Micah-Shalom Kesselman, Christopher Miller, and Matthew J. Smith. Finally, I received very helpful feedback during faculty workshops at Albany Law School, St. John's Law School, and Suffolk University Law School.

1. See, e.g., David A. Binder, Paul Bergman, Paul R. Tremblay \& Ian S. Weinstein, Lawyers as Counselors: A Client-Centered Approach (3d ed. 2011); Monroe H. Freedman \& AbBe Smith, Understanding Lawyers' Ethics (4th ed. 2010); W. Bradley Wendel, LAWYers AND Fidelity to LAW (2010); Charles Fried, The Lawyer as Friend: The Moral Foundations of the Lawyer-Client Relation, 85 YALE L.J. 1060 (1976); Stephen L. Pepper, The Lawyer's Amoral Ethical Role: A Defense, a Problem, and Some Possibilities, 1986 AM. B. Found. RES. J. 613. 
so-called dominant view suggest that the lawyer should take into account other considerations, such as the interests of justice or morality. ${ }^{2}$

One important practical problem with these competing prescriptions is that they do not help lawyers avoid unethical conduct. For example, even though the dominant view requires lawyers to protect the potentially discoverable documents only to the extent permissible under the law, lawyers who claim to be following the dominant view often cross the line. ${ }^{3}$ Similarly, prosecutors who are committed to the pursuit of justice regularly fail to comply with their constitutional obligations to disclose material, exculpatory information to defense counsel. ${ }^{4}$ These failures raise an important question: Why do lawyers who subjectively believe they are complying with prevailing theories of legal ethics-whether the dominant view or its alternatives - fail to apply the theories in the manner scholars intend?

This Article suggests that the answer lies in social psychology. A vast body of research reveals that situational factors, like placing a lawyer in a partisan role, can result in behavior that is inconsistent with conventional ethics theories. ${ }^{5}$ This Article suggests that legal ethicists can develop more accurate and useful theories by accounting for the ways in which partisanship distorts objectivity, just as behavioral economists have drawn on social psychology to develop more accurate and useful understandings of economics. ${ }^{6}$

Part I of this Article offers a brief overview of the well-established debate over the lawyer's professional role and contends that existing theories rest on an unacknowledged assumption about human behavior. The assumption, referred to here as the objective-partisan assumption, is that lawyers are capable of acting as partisans - being affiliated with one side of a matter-while remaining sufficiently objective about their own conduct to resolve ethical dilemmas in the manner theorists prescribe.

Part II contends that the objective-partisan assumption is flawed in light of what social science tells us about partisanship's distorting influence. For example, one recent study showed that accountants are more likely to find that a company's financial reports comply with generally accepted accounting principles when the accountants are placed in the role of the company's accountant than when they are assigned the role of the accountant for an outside investor in the same company. ${ }^{7}$ In other words, the accountants had some difficulty retaining their objectivity when

2. See David Luban, Lawyers and Justice: An Ethical Study (1988); William H. Simon, The Practice of Justice: A Theory of Lawyers' Ethics (1998).

3. See John S. Beckerman, Confronting Civil Discovery's Fatal Flaws, 84 MinN. L. Rev. 505, 524-34 (2000); Barbara J. Gorham, Note, Fisons: Will It Tame the Beast of Discovery Abuse?, 69 WASH. L. REV. 765 (1994).

4. See Editorial, Rampant Prosecutorial Misconduct, N.Y. TIMES, Jan. 5, 2014, at SR 10; Brad Heath \& Kevin McCoy, Prosecutors' Conduct Can Tip the Scales, USA TodAY, Sept. 23, 2010, at A1; see also Alafair S. Burke, Improving Prosecutorial Decision Making: Some Lessons of Cognitive Science, 47 WM. \& MARY L. REV. 1587 (2006).

5. See infra Part II.

6. See generally Daniel Kahneman, Thinking, Fast And Slow (2011) (offering an overview and history of the field).

7. Don A. Moore, Lloyd Tanlu \& Max H. Bazerman, Conflict of Interest and the Intrusion of Bias, 5 JUdGMENT \& DeCISION MAKING 37 (2010). 
they were placed in a partisan position. ${ }^{8}$ Studies reveal that lawyers have trouble remaining objective under similar circumstances. For instance, lawyers have a tendency to offer different assessments of the objective value of a case depending on whether they are asked to represent the plaintiff or the defendant. ${ }^{9}$ These studies, and others like them, ${ }^{10}$ suggest that partisanship has a tendency to distort professional judgments.

Part III contends that, in light of these findings, prevailing legal ethics theories contain questionable prescriptions. Consider, for example, the dominant view of legal ethics, which posits that lawyers should pursue a client's demands to the full extent the law allows. ${ }^{11}$ The research on partisanship strongly implies that lawyers who adopt this view will have difficulty identifying the line between permissible and impermissible advocacy and that compliance with the dominant view will result in misconduct more often than dominant-view proponents acknowledge. ${ }^{12}$ The research also suggests that theories critical of the dominant view suffer from similar problems. ${ }^{13}$

Part IV explores how behavioral insights could make existing theories more realistic and helpful. For instance, theorists could acknowledge that lawyers have difficulty making ethical judgments in ambiguous situations and that, in those contexts, lawyers should employ debiasing strategies, such as seeking second opinions from trusted colleagues who are not working on the same matter or reaching out to the ethics committees of local bar associations. ${ }^{14}$ These debiasing strategies are not a panacea (in part because ethical issues are difficult to spot and because colleagues can have partisanship biases in favor of the client as well),${ }^{15}$ but they can increase the likelihood that lawyers will act as legal ethics theorists intend.

Other strategies include exposing law students to the increasingly vast literature on how cognitive errors lead to poor decision making and drafting rules and policies that reflect partisanship's distorting influence. For example, given that prosecutors regularly make mistakes when deciding whether to disclose information to a defendant, ${ }^{16}$ theorists

8. See id. at 46 .

9. See Linda Babcock, George Loewenstein, Samuel Issacharoff \& Colin Camerer, Biased Judgments of Fairness in Bargaining, 85 AM. ECON. REV. 1337 (1995) (finding that lawyers' assessments of the value of a case vary depending on which side the lawyers are assigned to represent).

10. See infra Part II.B.

11. See, e.g., BINDER ET AL., supra note 1; FREEDMAN \& SMITH, supra note 1; Fried, supra note 1; Pepper, supra note 1.

12. See infra Part II.B.

13. See infra Part III.B.

14. The recommendation to seek second opinions is not new. See Geoffrey C. Hazard, Jr., Foreword, The Legal Profession: The Impact of Law and Legal Theory, 67 FoRDHAM L. REV. 239, 247 (1998) ("A lawyer confronting something that seems to be an ethics problem should consult a colleague about whether there is such a problem and, if so, how she should go about resolving it."). But it has not previously been discussed in the context of the prevailing ethics theories. Moreover, prior discussions tend not to draw on social science research, which suggests that second opinions offer only a partial solution to the problem. See infra notes 153-155 and accompanying text.

15. See infra notes 153-156 and accompanying text.

16. See supra note 4 and accompanying text. 
could prescribe the greater use of an "open-file policy," 17 which gives the accused access to all information in the prosecutor's file. This kind of policy would reduce the distorting effect of partisanship and increase the odds that prosecutors will behave as theorists prescribe.

In sum, this Article contends that behavioral research can inform the foundational legal ethics debate in ways that have not been fully explored. To be clear, a number of scholars have drawn on social psychology to develop many useful insights about specific problems in the field of professional responsibility, ${ }^{18}$ as well as other fields

17. Ellen Yaroshefsky, Prosecutorial Disclosure Obligations, 62 Hastings L.J. 1321, 1330 (2011).

18. See, e.g., Milton C. Regan Jr., Eat What You Kill: The Fall of a Wall Street LAWYer 291-351 (2004); JenNifer K. RobBenNolt \& JEAN R. STERnLight, Psychology FOR LAWYERS: UndERSTANDING THE HuMAN FACTORS IN NEGOTIATION, Litigation, AND DECiSION MAKING 385-416 (2012); Anthony V. Alfieri, The Fall of Legal Ethics and the Rise of Risk Management, 96 GEO. L.J. 1909, 1939 (2006) (arguing that risk-management systems impede moral decisions by diminishing individual responsibility and inducing moral apathy); Lawrence J. Fox, I'm Just an Associate . . a at a New York Firm, 69 FordHAm L. ReV. 939 (2000) (contending that students should be exposed to common social psychology themes in legal ethics courses); Neil Hamilton \& Verna Monson, The Positive Empirical Relationship of Professionalism to Effectiveness in the Practice of Law, 24 GeO. J. Legal ETHICs 137, 18485 (2011) (arguing that law firm professional-development programs should combat organizational cultures' encouragement of unethical behavior); Art Hinshaw \& Jess K. Alberts, Doing the Right Thing: An Empirical Study of Attorney Negotiation Ethics, 16 HARV. NeGot. L. ReV. 95, 100 (2011) (showing existence of "pervasive cultural and structural problem" in how lawyers think about negotiations); Pam Jenoff, Going Native: Incentive, Identity, and the Inherent Ethical Problem of In-House Counsel, 114 W. VA. L. REV. 725 (2012) (arguing that corporate "cultural immersion" makes it difficult for in-house attorneys to remain independent); Sung Hui Kim, Gatekeepers Inside Out, 21 GeO. J. Legal Ethics 411 (2008) (using social psychology to suggest ways to gain insights into "long-held assumptions" about gatekeeping); Donald C. Langevoort, Getting (Too) Comfortable: In-House Lawyers, Enterprise Risk, and the Financial Crisis, 2012 WIS. L. REV. 495 (discussing how cognitive biases may affect in-house lawyers); Richard Lavoie, Subverting the Rule of Law: The Judiciary's Role in Fostering Unethical Behavior, 75 U. Colo. L. REV. 115, 121-35 (2004) (positing that situational factors, not intrinsic characteristics, produce unethical behavior); Alan M. Lerner, Using Our Brains: What Cognitive Science and Social Psychology Teach Us About Teaching Law Students To Make Ethical, Professionally Responsible, Choices, 23 QUINNIPIAC L. REV. 643 (2004) (contending that professional-responsibility courses are not training future lawyers to make ethical choices); Leslie C. Levin, Bad Apples, Bad Lawyers or Bad Decisionmaking: Lessons from Psychology and from Lawyers in the Dock, 22 GEO. J. Legal Ethics 1549 (2009) (reviewing Richard L. ABEL, LAWYERS IN THE Dock: LEARNing From Attorney Discipline ProceEdings (2008) and discussing how commitments to a course of conduct and self-deception may cause lawyers to act unethically); Robert L. Nelson, The Discovery Process As a Circle of Blame: Institutional, Professional, and Socio-Economic Factors That Contribute to Unreasonable, Inefficient, and Amoral Behavior in Corporate Litigation, 67 FordHAM L. REV. 773 (1998) (identifying factors contributing to unethical behavior among civil litigators in large law firms); Andrew M. Perlman, Unethical Obedience by Subordinate Attorneys: Lessons from Social Psychology, 36 HoFSTRA L. REV. 451 (2007) (discussing effects of conformity and obedience to authority on subordinate lawyers' ethics); W. Bradley Wendel, Ethical Lawyering in a Morally Dangerous World, 19 GEO. J. LegAL Eтнісs 299 (2006) (highlighting and offering tips for combatting subtle situational forces 
of law. ${ }^{19}$ The basic theories of legal ethics, however, have remained largely unchallenged and unaffected by developments in social science. ${ }^{20}$ Moreover, the literature has not fully examined how partisanship — a central and ubiquitous feature of lawyering — can affect lawyers' ethical decision making. This Article seeks to fill those gaps with the goal of producing more accurate and useful descriptions of, and prescriptions for, lawyer conduct.

\section{THE OBJeCtive-PARTISAN AsSUMPTION IN LEGAL ETHICS THEORY}

Existing theories of legal ethics contain an important and largely unexamined assumption - that lawyers are simultaneously capable of partisanship on behalf of clients while remaining sufficiently objective to ensure that their own conduct is ethical. This assumption, which is referred to here as the objective-partisan assumption, can be found in all of the leading theories of legal ethics.

At the outset, it is important to be clear what is meant by "partisanship" and how it differs from the legal ethics concept often referred to as the "partisanship principle." 21 Traditionally, the partisanship principle has been understood as one aspect of the dominant view of legal ethics - that lawyers should, "within the established constraints on professional behavior, maximize the likelihood that the client's objectives will be attained." 22 Put more simply, a lawyer should pursue a client's cause to the full extent the law allows.

The word "partisan," however, has a different meaning in social psychology. In that context, it is commonly used to describe people who fit the dictionary definition of a "partisan," that is, those who are adherents to, or aligned with, a specific "party, faction, cause, or person." 23 So lawyers may be partisans in the social-psychology sense (i.e., adhering to a specific party or cause) without complying with the partisanship principle (i.e., pursuing that client's cause as far as the law allows). The distinction is significant because critics of the dominant view reject the partisanship principle but acknowledge that lawyers are partisans in the sense of being aligned with a particular side of a matter. ${ }^{24}$ Unless otherwise specified, this Article refers to "partisanship" in the latter sense.

affecting lawyer behavior); see also infra note 75.

19. See generally IdeOlogy, Psychology, AND LaW (Jon Hanson ed., 2012).

20. But see Alice Woolley \& W. Bradley Wendel, Legal Ethics and Moral Character, 23 GeO. J. LEGAL EthiCs 1065 (2010) (describing varied assumptions about human behavior implicit in different theories of legal ethics).

21. See, e.g., WENDEL, supra note 1, at 6 (listing the "[p]rinciple of [p]artisanship" as one of the "two principles that guide the actions of lawyers"); Daniel Markovits, Further Thoughts About Legal Ethics from the Lawyer's Point of View, 16 YALE J.L. \& HumAN. 85, 109 (2004) ("[T]he partisanship principle . . . remains, as Geoffrey Hazard has said, 'at the core of the profession's soul.'” (quoting Geoffrey C. Hazard, Jr., The Future of Legal Ethics, 100 YALE L.J. 1239, 1245 (1991))); Andrew M. Perlman, A Career Choice Critique of Legal Ethics Theory, 31 Seton Hall L. Rev. 829, 846-50 (2001) (providing an overview of the "partisanship principle").

22. See LubAN, supra note 2, at 12.

23. See Merriam-Webster's Collegiate Dictionary 904 (11th ed. 2012).

24. See LuBAN, supra note 2, at 12-13; SimON, supra note 2, at 9-10. 


\section{A. The Dominant View's Objective-Partisan Assumption}

The dominant view contains several related ideas, but one important principle is that lawyers should pursue all lawful and ethical conduct a client requests. ${ }^{25}$ Supporters of this approach argue that it is a critical feature of the adversarial system, ${ }^{26}$ or that it is an extension of the agency and fiduciary responsibilities at the core of the attorney-client relationship. ${ }^{27}$ They also argue that the dominant view furthers human dignity, ${ }^{28}$ autonomy, ${ }^{29}$ due process rights, ${ }^{30}$ and clients' trust and confidence in their lawyers. ${ }^{31}$

The dominant view is conceptually appealing, but it necessarily relies on the objective-partisan assumption. According to the dominant view, a lawyer should pursue a client's interests to the full extent the law allows without crossing the line between permissible and impermissible conduct. ${ }^{32}$ This prescription necessarily assumes that lawyers are capable of acting as partisans - representing one side of a matter-and actually identifying the line between permissible and impermissible behavior. Critically, if lawyers cannot consistently and accurately locate that line, compliance with the dominant view would produce impermissible conduct more often than the theory's proponents acknowledge and produce the ironic effect of undermining rather than promoting the client's objectives.

Consider a couple of examples. First, recall the hypothetical at the beginning of this Article: a client gives a lawyer several smoking-gun documents that may doom the client's case if produced in discovery, and the client instructs the lawyer to use all permissible methods to avoid producing the documents. Under these circumstances, the dominant view requires the lawyer to pursue every lawful tacticto go right up to the line, but not cross it. ${ }^{33}$ The problem is that, if the lawyer is encouraged to approach a line that the lawyer cannot clearly identify, the lawyer is at a heightened risk of engaging in impermissible behavior, such as withholding the documents under a frivolous theory of privilege or unresponsiveness. ${ }^{34}$ Such

25. See WENDEL, supra note 1, at 6; Fried, supra note 1, at 1066; Pepper, supra note 1, at 614. As explained in more detail above, this principle is sometimes referred to as the partisanship principle. See supra note 22 and accompanying text (discussing the partisanship principle's meaning in the context of lawyering). To avoid confusion, the Article will continue to refer to the partisanship principle as the dominant view, and the word "partisan" will continue to be used in the ordinary dictionary sense of the word, which is more common in the social psychology literature.

26. See, e.g., Marvin E. Frankel, Partisan Justice 12 (1980); Murray L. Schwartz, The Professionalism and Accountability of Lawyers, 66 CALIF. L. REV. 669, 671 (1978).

27. See FreEdman \& SMith, supra note 1 , at 260.

28. Id. at 56-57, 69-70.

29. Id.

30. Id. at $25-29$.

31. Id. at $128-29$.

32. See LuBAN, supra note 2, at 11-12.

33. See W. Bradley Wendel, Busting the Professional Trust: A Comment on William Simon's Ladd Lecture, 30 FlA. ST. U. L. REV. 659, 663 (2003) (observing that adversarial discovery practice is one feature of the dominant view).

34. See Washington State Physicians Ins. Exch. \& Ass'n v. Fisons Corp., 858 P.2d 1054, 1079-85 (Wash. 1993); Beckerman, supra note 3, at 524-34; Gorham, supra note 3. 
behavior not only threatens the lawyer's interests, but the client's as well. For this reason, proponents of the dominant view necessarily have to assume that the lawyer is an objective partisan - capable of advocating for the client regarding the production issue and reliably determining the line between permissible and impermissible advocacy.

Second, imagine a lawyer suspects that a client plans to perjure herself at trial. Under the Model Rules, the lawyer is permitted (or required if it is a criminal case) to offer the client's testimony if the lawyer "reasonably believes" the testimony will be false. ${ }^{35}$ In contrast, the lawyer is prohibited from offering the testimony if the lawyer "knows" it will be false. ${ }^{36}$ According to the dominant view, if the client insists on testifying, the lawyer should offer the testimony unless the lawyer comes to "know" the testimony will be false. ${ }^{37}$ The problem is that, when acting as a partisan, the lawyer is at an increased risk of concluding that she "reasonably believes" the testimony is false when she really "knows" it to be false. Again, to avoid this practical side effect of the dominant view, theorists necessarily (albeit implicitly) assume the lawyer is an objective partisan.

The objective-partisan assumption also appears in variants of the dominant view. In an important recent book, Professor Bradley Wendel argues that lawyers should not necessarily pursue all of a client's "interests" to the full extent that the law allows; rather, he contends that lawyers should pursue only a client's "legal entitlements" and only to the extent that those entitlements are "well grounded." 38 Wendel's approach is conceptually distinct from the dominant view, but it too relies on the objective-partisan assumption. Namely, Wendel implicitly assumes that a lawyer has sufficient objectivity to determine whether a proposition is well grounded even when acting as a partisan. This assumption may be sound when the answer is clear (i.e., a particular legal proposition is obviously, or obviously not, well grounded). But when a legal proposition is closer to the line, such as in the perjury example above, Wendel does not discuss if a lawyer will be capable of acting as a partisan and making an objective assessment of whether the client's position is well grounded.

The point here is not that lawyers will be unable to identify the line separating permissible and impermissible conduct in all, or even most, instances when they follow the dominant view or its variants. Rather, the claim is that theorists have

35. Model Rules of Prof'L Conduct R. 3.3(a)(3) (2013) (prohibiting lawyers from offering "evidence that the lawyer knows to be false").

36. Id.

37. It is worth noting that some dominant view theorists, such as Monroe Freedman, believe the Model Rule should be changed to permit criminal defense lawyers to offer perjured testimony. See Monroe H. Freedman, Getting Honest About Client Perjury, 21 Geo. J. LegAL ETHICs 133, 136 (2008). This prescription for a change to the positive law is beyond the scope of this Article. For a discussion of the distinction between using legal ethics theory to inform the positive law and using it to guide lawyers' behavior in light of the extant rules, see Andrew M. Perlman, Untangling Ethics Theory from Attorney Conduct Rules: The Case of Inadvertent Disclosures, 13 Geo. MASON L. REV. 767 (2005).

38. See WENDEL, supra note 1, at 8. For other recent variations of the dominant view, see Daniel Markovits, A Modern Legal Ethics: Adversary Advocacy in a Democratic Age (2008) and Geoffrey C. Hazard, Jr. \& Dana A. Remus, Advocacy Revalued, 159 U. PA. L. REV. 751 (2011). 
not acknowledged their reliance on the objective-partisan assumption or analyzed its accuracy.

\section{B. The Critiques of Zealous Advocacy}

Critics of the dominant view also fail to acknowledge the objective-partisan assumption, ${ }^{39}$ resulting in two independent problems. First, as a result of the oversight, the critics have not identified a potential weakness in the dominant view - that lawyers may be unable to locate the line between vigorous advocacy and impropriety in the objective manner that dominant-view theorists assume to be possible.

Second, and less obviously, the critics do not recognize that they also rely on the objective-partisan assumption, causing the prescriptive power of their alternate theories to suffer accordingly. Consider, for example, Professor David Luban's critique of zealous advocacy ${ }^{40} \mathrm{He}$ contends that lawyers should seek morally worthy ends using morally justifiable means. ${ }^{41} \mathrm{~A}$ lawyer should be able to engage in this kind of moral calculus in extreme cases because the ends or means will be obviously moral or immoral. The problem is that Luban also assumes that lawyers will be able to engage in this analysis in more ambiguous situations. That is, he assumes that lawyers are capable of acting as partisans (in the sense of being aligned with one side of a matter) while making independent moral assessments about the client's ends or the selected means. In other words, he assumes lawyers are objective partisans.

Professor William Simon has offered another oft-cited critique of the dominant view. ${ }^{42}$ Simon posits that "[1]awyers should take those actions that, considering the relevant circumstances of the particular case, seem likely to promote justice." 43 Lawyers, according to this view, should not pursue their own unique conception of justice or morality but should be guided by a concept of justice that is consistent with the legal culture's understanding of the concept. ${ }^{44}$

The problem is that Simon assumes that lawyers are capable of making objective assessments about whether their conduct is consistent with the legal culture's understanding of justice. For example, prosecutors generally pursue the interests of justice. Yet, as explained earlier, they often fail to comply with their ethical and constitutional obligations to disclose material, exculpatory information to the accused..$^{45}$ Simon fails to acknowledge that lawyers necessarily interpret what justice

39. See Nathan M. Crystal, Developing a Philosophy of Lawyering, 14 Notre Dame J.L. ETHics \& PUB. POL'Y 75, 89-90 (2000); Hazard \& Remus, supra note 38, at 752-53 (offering an overview of critiques of the dominant view, none of which focus on the dominant view's failure to consider insights from social psychology); Pepper, supra note 1, at $614 \mathrm{n} .7$ (collecting criticisms of the dominant view).

40. See generally LuBAn, supra note 2 .

41. See id. at xxii; see also Thomas L. ShafFer \& Robert F. Cochran, JR., LAWyers, Clients, and Moral Responsibility (2d ed. 2009); Thomas L. Shaffer, On Being a CHRISTIAN AND A LAWYER: LAW FOR THE INNOCENT (1981).

42. See Simon, supra note 2, at 138-39; William H. Simon, Ethical Discretion in Lawyering, 101 HARV. L. REV. 1083 (1988).

43. SimON, supra note 2, at 138.

44. See id.

45. See supra note 4 and accompanying text. 
requires through the lens of their institutional role and thus may have difficulty applying his theory in the manner he prescribes.

In sum, theories of legal ethics emphasize a number of principles and values, but the theories all implicitly rely on an important assumption: that lawyers are capable of objectively determining the actions they are supposed to pursue while engaged in a role that necessarily entails some degree of partisanship. Whether this assumption relies on an accurate model of human behavior is rarely discussed.

\section{LESSONS FROM SOCIAL PSYCHOLOGY ABOUT OBJECTIVITY}

Social science research reveals that the objective-partisan assumption is problematic. Numerous studies demonstrate that our perceptions are easily distorted by the situations in which those perceptions occur and that partisanship can have a particularly strong distorting effect. ${ }^{46}$ These studies offer powerful evidence that lawyers will have more difficulty making objective assessments on issues - such as whether a course of conduct is legal, moral, or consistent with conceptions of justice- than most theorists acknowledge. ${ }^{47}$

\section{A. An Introduction to Relevant Concepts from Social Psychology}

In his recent book, Thinking, Fast and Slow, Nobel Prize winner Daniel Kahneman explains that we process information in two basic, but distinct, ways. ${ }^{48}$ One involves "fast" thinking, which causes us to reach rapid conclusions without conscious awareness. ${ }^{49}$ For example, if a person approaches us quickly with a menacing stare, we automatically and unconsciously interpret the person as hostile. ${ }^{50}$ No conscious thought is required to perceive the approaching person's emotional state.$^{51}$ In contrast, our brains process other kinds of information in a slower, more deliberate fashion, such as when we try to solve a complex math problem. ${ }^{52}$ In these situations, we consciously direct our attention to a question and search for a solution. ${ }^{53}$ Although Kahneman notes that these two methods of processing information are simplifications and often operate simultaneously, ${ }^{54}$ the concepts are helpful in understanding why the objective-partisan assumption is flawed.

46. See infra Part II.B.

47. Legal ethics theorists tend to assume that lawyers are immune not only to the effects of partisanship but also to other situational forces that tend to undermine objectivity, such as the range of biases and heuristics described in Part II. This Article focuses primarily on partisanship because it is such a central feature of the professional role and has been shown to have important effects on perceptions. Legal ethics theories may be incomplete in other respects as well.

48. See Kahneman, supra note 6, at 20-24.

49. See id. at 20.

50. See id. at 19-20.

51. See id.

52. See id. at 20.

53. See id.

54. See id. at 28-30. 
Consider how "fast" thinking causes us to misperceive simple stimuli, such as the size of an object or the sound of a voice. This illusion, created by psychologist Roger Shepard, ${ }^{55}$ offers a useful illustration:
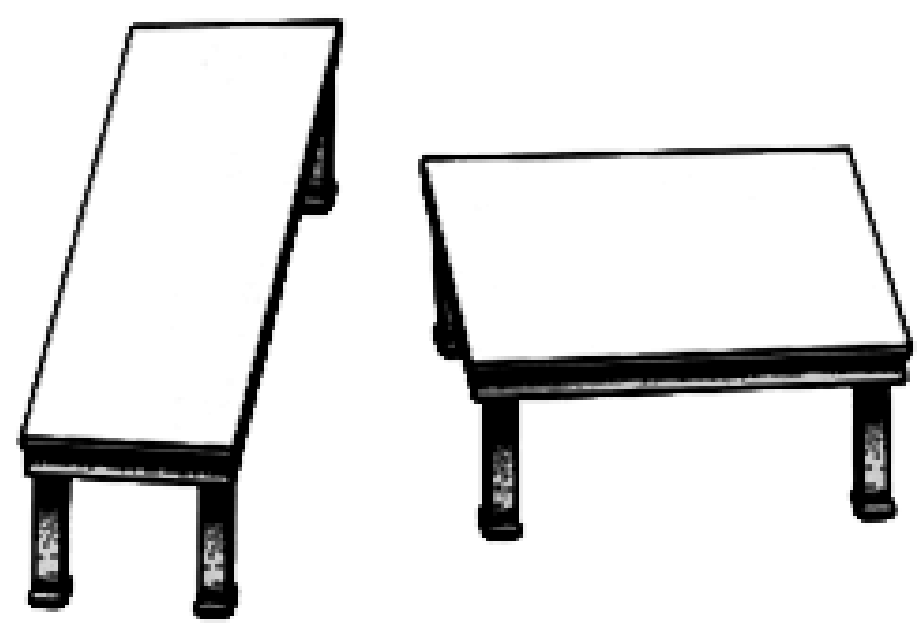

Figure 1. The Shepard Tabletop Illusion.

The tops of these tables appear to be different shapes, but they are actually the same length and width. ${ }^{56}$ (To prove it, trace the top of one table and place the tracing on top of the other table.) Here, "fast" thinking causes us to misinterpret the image. One explanation is that our brains perceive the table on the left as a three-dimensional object extending into the distance, so we interpret that image as longer and narrower than it really is..$^{57}$

Even our hearing can be affected by fast thinking. Consider the McGurk effect, ${ }^{58}$ which is created through the use of a video in which someone is shown speaking the syllable "ga" repeatedly, but the audio is dubbed so that listeners actually hear the orator saying the syllable "ba." ${ }^{\circ 9}$ Most people who watch the speaker's lips believe that the orator is saying "da," even though the actual sound is "ba." 60 The accurate sound is heard by looking away from the speaker's lips. As with the tabletop illusion,

55. See Roger N. Shepard, Mind Sights: Original Visual Illusions, Ambiguities, and Other Anomalies, with a Commentary on the Play of Mind in Perception and Art 48 (1990).

56. See id. at 46,48 .

57. See Christopher W. Tyler, Paradoxical Perception of Surfaces in the Shepard Tabletop Illusion, 2 I-PERCEPTION 137 (2011), available at http://i-perception.perceptionweb.com/fulltext /i02/i0422.pdf.

58. See Harry McGurk \& John MacDonald, Hearing Lips and Seeing Voices, 264 NATURE 746, 746-48 (1976). A sample video illustrating the effect can be found easily online. See The McGurk Effect, YouTuBe (July 3, 2006), http://www.youtube.com/watch?v=aFPtc8BVdJk.

59. Audrey R. Nath \& Michael S. Beauchamp, A Neural Basis for Interindividual Differences in the McGurk Effect, a Multisensory Speech Illusion, 59 NEUROIMAGE 781, 781 (2012) (providing an overview of research on the McGurk effect).

60. See id. 
our fast brains rely on past information about what we are perceiving (here, the movement of lips) and interpret the stimulus accordingly. In essence, basic perceptions of sight and sound can be distorted because our fast brains automatically (and sometimes erroneously) fill in information for us. ${ }^{61}$

Unconscious and automatic cognitive processes, such as heuristics and biases, similarly influence our perceptions of more complex situations. ${ }^{62}$ Heuristics, or mental shortcuts, help us navigate the world without the need to assess every new situation from scratch. ${ }^{63}$ For example, heuristics help us to prepare for the person with the menacing stare without having to spend valuable time consciously appraising the person's emotional state. If the person is, in fact, a threat, this form of fast thinking serves an important function.

Heuristics and biases, though helpful, also come with a cost: they make us prone to mistakes of judgment and perception in a wide range of situations. For example, we regularly and unconsciously conform our opinions to the expressed beliefs of those around us, even when those beliefs are ethically questionable (also known as "groupthink"). ${ }^{64} \mathrm{We}$ are willing to obey an unethical instruction because of unconscious cues, such as the clothes someone is wearing or whether the person issuing the instruction is perceived as a legitimate authority figure. ${ }^{65} \mathrm{We}$ have implicit biases concerning a wide range of personal traits, such as race, gender, religion, and physical appearance, even in the absence of any conscious bias or

61. See id. at 785 (discussing finding that McGurk perceivers demonstrated increased neural responses in the left superior temporal sulcus).

62. See Kahneman, supra note 6, at 107-95. See generally LeE Ross \& Richard E. Nisbett, The Person and the Situation: Perspectives of Social Psychology (1991).

63. See KAHNEMAN, supra note 6, at 28 .

64. See generally Solomon E. Asch, Studies of Independence and Conformity: I. A Minority of One Against a Unanimous Majority, 70 Psychol. MonOGRAPHS: GEN. \& APPLIED, no. 9, 1956, at 1 . The effect can occur even among skilled professionals. See Dina Badie, Groupthink, Iraq, and the War on Terror: Explaining US Policy Shift Toward Iraq, 6 FOREIGN POL'Y ANALYSIS 277 (2010) (attributing the change in the Bush administration's views on and eventual invasion of Iraq to groupthink).

65. See generally Stanley Milgram, Obedience to Authority: An Experimental VIEW (Perennial Classics 2004) (1974). The premise that clothes, for example, can affect one's willingness to obey instructions has been repeatedly tested and confirmed. See, e.g., Leonard Bickman, The Social Power of a Uniform, 4 J. APPLIED Soc. PsychOl. 47 (1974) (connecting subject's compliance with orders of uniform-wearing individuals to the belief that uniformed individuals have legitimacy); Brad J. Bushman, The Effects of Apparel on Compliance: A Field Experiment with a Female Authority Figure, 14 Personality \& Soc. Psychol. Bull. 459, 459-62, 464-65 (1988) (finding that compliance rates are higher when an order is given by a uniformed individual); Marcy Strauss, Reconstructing Consent, 92 J. CRIM. L. \& CRIMINOLOGY 211, 236 (2001) ("Numerous scholars and even judges have made the very basic observation that most people would not feel free to deny a request by a police officer." (citing Tracey Maclin, "Black and Blue Encounters"-Some Preliminary Thoughts About Fourth Amendment Seizures: Should Race Matter?, 26 VAL. U. L. REV. 243, 249-50 (1991) ("Common sense teaches that most of us do not have the chutzpuh or stupidity to tell a police officer to 'get lost' after he has stopped us and asked for identification or questioned us about possible criminal conduct."))). 
prejudice ${ }^{66}$ We have a tendency to interpret information in ways that confirm our preexisting views ${ }^{67}$ we tend to be unduly optimistic about our prospects for the future; ${ }^{68}$ we miscalculate the frequency of events based on how available they are in our memory (the representative heuristic); ${ }^{69}$ we tend to place a greater monetary value on items we own than on items we want to acquire (the endowment effect) $;^{70}$ and we attribute unwarranted significance to numbers we hear that have no rational relationship to decisions we need to make (the anchoring effect). ${ }^{71}$ These and numerous other well-documented heuristics and biases regularly cause us to make errors of judgment and perception and to act in ways that are inconsistent with the

66. See generally MahZARin R. BANAJi \& ANTHONy G. GReEnWALd, Blindspot: Hidden Biases of Good People (2013); Jerry Kang et al., Implicit Bias in the Courtroom, 59 UCLA L. REV. 1124 (2012) (documenting a range of implicit biases affecting the justice system). An increasingly robust literature demonstrates that these biases also affect professionals. See Alexander R. Green et al., Implicit Bias Among Physicians and Its Prediction of Thrombolysis Decisions for Black and White Patients, 22 J. Gen. InTERnAl Med. 1231, 1231 (2007) (concluding that "physicians' unconscious biases may contribute to racial/ethnic disparities in use of medical procedures such as thrombolysis for myocardial infarction"); Jeffrey J. Rachlinski, Sheri Lynn Johnson, Andrew J. Wistrich \& Chris Guthrie, Does Unconscious Racial Bias Affect Trial Judges?, 84 Notre DAME L. ReV. 1195 (2009) (reviewing implicit bias research relating to judges).

67. See Charles G. Lord, Lee Ross \& Mark R. Lepper, Biased Assimilation and Attitude Polarization: The Effects of Prior Theories on Subsequently Considered Evidence, $37 \mathrm{~J}$. Personality \& Soc. Psychol. 2098, 2098 (1979) (concluding those who have strong opinions on complex issues are "likely to examine relevant empirical evidence in a biased manner"). Biases can also dictate behavior, which, in turn, may confirm the initial bias. See Carole Hill, Amina Memon \& Peter McGeorge, The Role of Confirmation Bias in Suspect Interviews: A Systematic Evaluation, 13 LEgAL \& CRiminOLOGICAL PsYCHOL. 357, 357 (2008) (concluding "expectations of guilt can indeed have an effect on questioning style and that this in-turn [sic] can lead to a self-fulfilling prophecy effect").

68. See Tali Sharot, Alison M. Riccardi, Candace M. Raio \& Elizabeth A. Phelps, Neural Mechanisms Mediating Optimism Bias, 450 NATURE 102, 102 (2007) (discussing the often-incorrect tendencies of individuals to make "overly confident, positive predictions about the future," and how the brain generates the optimism bias).

69. For example, people often believe that homicides occur more often than suicides because the media portrays the former with greater frequency than the latter. See Valerie S. Folkes, The Availability Heuristic and Perceived Risk, 15 J. CONSUMER RES. 13, 13 (1988); see also KAHNEMAN, supra note 6, at 151-52.

70. See KAhneman, supra note 6, at 289-99. But see Gregory Klass \& Kathryn Zeiler, Against Endowment Theory: Experimental Economics and Legal Scholarship, 61 UCLA L. REV. 2 (2013) (questioning the endowment effect).

71. See Kahneman, supra note 6, at 119-128 (discussing the anchoring effect). The anchoring effect causes our estimations of a number to be anchored by a random number we previously heard. See id. For example, if you were asked whether George Washington was more than ninety-three years old at the time of his death, you would typically estimate his age at death to be higher than you would if the anchoring question used the age of forty-two instead. See id. at 119-20 (using Gandhi's age in a similar example). Lawyers are subject to this effect as well, such as when they negotiate the settlement value of a case. See Dan Orr \& Chris Guthrie, Anchoring, Information, Expertise, and Negotiation: New Insights from Meta-Analysis, 21 Оніо ST. J. ON Disp. Resol. 597, 597-98 (2006). 
oft-assumed model of human objectivity and rationality. ${ }^{72}$ Put simply, we have "bounded rationality.",73

A number of scholars have explored the implications of these and related concepts for lawyers. ${ }^{74}$ This literature is increasingly vast and varied, and some scholars (such as Professor Donald Langevoort) have spent considerable time over many years writing about the subject in the legal ethics context. ${ }^{75}$ The role of partisanship, however, generally receives limited attention. ${ }^{76}$ This oversight is surprising because partisanship is a hallmark of the lawyer's professional role, has been shown to have important effects on human perception and action, and (as explained earlier) is assumed by legal ethics theorists to have no effect on lawyer objectivity.

\section{B. The Partisanship Problem}

This Section reviews existing research on partisanship. These studies reveal that partisans have difficulty assessing information objectively and that the objective-artisan assumption is problematic.

The first work in this area was conducted over sixty years ago. In a classic study on partisanship, students at Dartmouth and Princeton were shown a film of a combative football game between their respective schools in which both teams were regularly penalized for various rule violations. ${ }^{77}$ The students were asked to count the number of penalties by each team, classify the penalties as either "flagrant" or "mild," and identify the team that initiated the violation. ${ }^{78}$ Researchers found that the assessments of the Princeton and Dartmouth students were materially different. ${ }^{79}$ This study and others like it suggest that group affiliations affect perceptions. ${ }^{80}$

72. See generally KAHNEMAN, supra note 6 .

73. See Herbert A. Simon, Bounded Rationality and Organizational Learning, 2 OrG. SCI. 125 (1991).

74. See supra note 18.

75. See, e.g., Donald C. Langevoort, Ego, Human Behavior, and Law, 81 VA. L. ReV. 853 (1995); Langevoort, supra note 18; Donald C. Langevoort, What Was Kaye Scholer Thinking?, 23 LAW \& Soc. InQuiRy 297 (1998); Donald C. Langevoort, Where Were the Lawyers? A Behavioral Inquiry into Lawyers' Responsibility for Clients' Fraud, 46 VAND. L. ReV. 75 (1993) [hereinafter Where Were the Lawyers?].

76. But see Cassandra Burke Robertson, Judgment, Identity, and Independence, 42 ConN. L. REV. 1 (2009) (arguing that particular conditions or situational influences may trigger partisan biases that cloud a lawyer's judgment); Paula Schaefer, Harming Business Clients with Zealous Advocacy: Rethinking the Attorney Advisor's Touchstone, 38 FLA. ST. U. L. REV. 251, 257 (2011) (using social psychology to show that partisan bias may "shade and distort" the legal advice given to a client, how zealous advocacy is actually harmful to clients, and how revisions to professional conduct codes can prevent attorneys from turning to the zealous advocacy philosophy (quoting Robertson, supra, at 40)).

77. See Albert H. Hastorf \& Hadley Cantril, They Saw a Game: A Case Study, 49 J. ABNORMAL \& SOC. PSYCHOL. 129 (1954).

78. Id. at 130 .

79. Id. at $130-32$.

80. See Leon Mann, On Being a Sore Loser: How Fans React to Their Team's Failure, 26 AustL. J. PSYCHOL. 37 (1974). 


\section{Political Partisanship}

The effect is similar for political partisans. ${ }^{81}$ In one study, Democrats and Republicans were asked to evaluate a particular welfare policy ${ }^{82}$ The participants' assessment of the policy turned less on the perceived generosity of the policy and more on the party who proposed it. ${ }^{83}$ The study found that liberal participants tended to favor the conservative policy when told that Democrats proposed it, and conservative participants leaned towards the liberal policy when told that Republicans proposed it. ${ }^{84}$ Interestingly, both liberal and conservative participants claimed they were judging the policy based on its content, so neither side appeared to acknowledge partisanship's influence over their perceptions. ${ }^{85}$ Thus, as with the football study, individual affiliations affected perceptions.

Another conceptually similar study asked Israelis to assess Palestinian and Israeli peace proposals. ${ }^{86}$ When shown the Palestinian proposal, some subjects were (incorrectly) told that the Israelis made the proposal. ${ }^{87}$ Conversely, when shown the Israeli proposal, some subjects were (incorrectly) told that the Palestinians made the proposal. ${ }^{88} \mathrm{~A}$ control group was told the true identity of the side making each proposal. ${ }^{89}$ The study revealed that Israeli subjects had more positive feelings about the Palestinian plan when told that Israelis had proposed it than they did about the Israeli plan when told the Palestinians had proposed it. ${ }^{90}$ In other words, by changing the authorship of the plans, Israelis in the study stated a preference for the Palestinian plan over the Israeli plan, and vice versa. ${ }^{91}$

81. See, e.g., Larry M. Bartels, Beyond the Running Tally: Partisan Bias in Political Perceptions, 24 Pol. BeHAV. 117, 131 (2002); Geoffrey D. Munro, Terell P. Lasane \& Scott P. Leary, Political Partisan Prejudice: Selective Distortion and Weighting of Evaluative Categories in College Admissions Applications, 40 J. Applied Soc. Psychol. 2434, 2445 (2010); Conor Friedersdorf, This Is Your Brain on Partisanship-Any Questions?, THE ATLANTiC (Aug. 2, 2012), http://www.theatlantic.com/politics/archive/2012/08/this-is-yourbrain-on-partisanship-any-questions/260518/.

82. See Geoffrey L. Cohen, Party Over Policy: The Dominating Impact of Group Influence on Political Beliefs, 85 J. Personality \& Soc. Psychol. 808 (2003).

83. See id. at 811 ("For both liberal and conservative participants, the effect of reference group information overrode that of policy content.").

84. See id.

85. See id. at 808, 811-12, 821 .

86. Ifat Maoz, Andrew Ward, Michael Katz \& Lee Ross, Reactive Devaluation of an "Israeli” vs. "Palestinian” Peace Proposal, 46 J. CONFLict ReSol. 515 (2002).

87. See id. at 521.

88. See id.

89. See id.

90. See id. at 531-32.

91. See id.; cf. Russell B. Korobkin \& Thomas S. Ulen, Law and Behavioral Science: Removing the Rationality Assumption from Law and Economics, 88 CALIF. L. REV. 1051, 1092 (2000) (discussing overconfidence bias as it relates to targets of social policies). In another study on the "confirmatory" or "self-serving" bias, psychologists found that when two groups - one pro-capital punishment and one anti-capital punishment - were shown the same factual information about capital punishment, each group claimed that the information reinforced its prior beliefs. See id. at 1093 (citing Lord et al., supra note 67, at 2102). 
Another illustration of the effect can be found in U.S. surveys of attitudes about government surveillance programs. A 2013 Pew Research Center and Washington Post survey asked U.S. citizens about the National Security Agency's surveillance programs under President Barack Obama. ${ }^{92}$ An earlier poll had asked about similar programs under President George W. Bush. ${ }^{93}$ The 2013 survey found that, "while there are apparent differences between the NSA surveillance programs under the Bush and Obama administrations, overall public reactions to both incidents are similar." ${ }^{4}$ The survey revealed statistically significant differences, however, correlating with party affiliation:

Republicans and Democrats have had very different views of the two operations. Today, only about half of Republicans (52\%) say it is acceptable for the NSA to obtain court orders to track phone call records of millions of Americans to investigate terrorism. In January 2006, fully $75 \%$ of Republicans said it was acceptable for the NSA to investigate suspected terrorists by listing [sic] in on phone calls and reading emails without court approval.

Democrats now view the NSA's phone surveillance as acceptable by $64 \%$ to $34 \%$. In January 2006 , by a similar margin (61\% to $36 \%$ ), Democrats said it was unacceptable for the NSA to scrutinize phone calls and emails of suspected terrorists. ${ }^{95}$

These findings offer yet another example of how partisan bias can affect perception.

Of course, these kinds of results do not suggest that everyone is subject to partisan bias. After all, a majority of people in each political party retained their preexisting views on government surveillance regardless of who was in office. ${ }^{96}$ The point here is that political partisanship can affect some people's perceptions in particular situations.

\section{Professional Partisanship}

It is tempting to conclude that the football and political partisan studies are inapplicable to professionals (like lawyers) because, unlike sports fans and casual political partisans, professionals are more informed about the subject matter of their decisions and are trained to maintain their objectivity. Indeed, some research suggests, for example, that political partisans are less likely to rely on heuristics when they are more politically informed. ${ }^{97}$ Moreover, even when partisan biases exist, they

92. See Pew Research Center, Majority Views NSA Phone Tracking as ACCEPTABLE ANTI-TERROR TACTIC (2013), available at http://www.people-press.org /files/legacy-pdf/06-10-13\%20PRC\%20WP\%20Surveillance\%20Release.pdf.

93. See id. at 2 .

94. Id.

95. Id. at 3.

96. See Eugene Volokh, "Virtually Unyielding Preference for Partisanship Over Principle?”, VOLOKH CONSPIRACY (June 14, 2013, 5:08 PM), http://www.volokh.com /2013/06/14/virtually-unyielding-preference-for-partisanship-over-principle/.

97. See Cindy D. Kam, Who Toes the Party Line? Cues, Values, and Individual 
often affect only a fraction of individuals. ${ }^{98}$ These findings imply that knowledgeable professionals may be immune (or more fully immune) to partisan influences as a result of their knowledge and experiences.

Existing research, however, does not support this conclusion. Several studies demonstrate that lawyers tend to offer different assessments of a case's value depending on which side the lawyers are asked to represent. ${ }^{99}$ In one study, law students were asked to review a litigation case file and imagine they were representing one of the two sides. ${ }^{100}$ Although the facts given to each of the students were identical, the students interpreted the facts differently depending on which side they represented. ${ }^{101}$ Similarly, in a more recent study involving moot court participants, students overestimated the legal merits of the side they were randomly assigned to represent, even at the conclusion of the competition. ${ }^{102}$

These findings do not necessarily mean that a significant fraction of lawyers would be unable to make ethics-related decisions objectively. When extending the above findings to ethical choices, it is important to understand the heuristics responsible for the above results. One is the optimism bias, which is the tendency to imagine that our futures are going to be more positive (e.g., our health, our future wealth) than we should reasonably expect. ${ }^{103}$ This bias contributes to a lawyer's unduly optimistic vision of a case's prospects and thus partially explains why a lawyer would tend to overestimate the likelihood of succeeding in a particular matter.

A second important contributing factor, at least in studies where lawyers are asked to assess a case's monetary value, is the endowment effect, which causes us to demand more money to part with an item we own than we would be willing to pay someone else for the same item. ${ }^{104}$ This heuristic may help to explain why lawyers demand more money to settle cases they "own" (i.e., the plaintiff's side of a case) than they might be willing to pay if they had to "buy" the same case (i.e., by representing the defendant).

If these were the only two heuristics responsible for the perceptions lawyers had in the above studies, one might conclude that ethical decision making would not necessarily be affected. When making ethical decisions, lawyers are apt to be less susceptible to the endowment effect because, typically, there are no explicit

Differences, 27 Pol. BeHAV. 163 (2005).

98. See Volokh, supra note 96.

99. See, e.g., Babcock et al., supra note 9 (finding that lawyers' assessment of the value of a case varies dramatically depending on which side they represent); Zev J. Eigen \& Yair Listokin, Do Lawyers Really Believe Their Own Hype, and Should They? A Natural Experiment, 41 J. LEGAL STUD. 239, 239 (2012) (finding that "following participation in moot court contests, students overwhelmingly perceive that the legal merits favor the side that they were randomly assigned to represent"); Jane Goodman-Delahunty, Pär Anders Granhag, Maria Hartwig \& Elizabeth F. Loftus, Insightful or Wishful: Lawyers' Ability to Predict Case Outcomes, 16 Psychol. Pub. Pol'y \& L. 133, 133 (2010) (finding that "lawyers were overconfident in their [case outcome] predictions").

100. George Loewenstein, Samuel Issacharoff, Colin Camerer \& Linda Babcock, Self-Serving Assessments of Fairness and Pretrial Bargaining, 22 J. LEGAL STUD. 135 (1993).

101. See id. at $145-53$.

102. See Eigen \& Listokin, supra note 99.

103. See supra note 68 and accompanying text.

104. See supra note 70 and accompanying text. 
monetary valuations to make. Similarly, although the optimism bias may make a lawyer unduly optimistic about the outcome of a case, it does not necessarily make a lawyer unable to see the line between ethical and unethical conduct. ${ }^{105}$

Additional studies, however, suggest that partisanship itself - the mere placement of a professional on one side of a potentially disputed matter - can have a distorting effect on professionals' perceptions and judgments, even when the optimism bias and the endowment effect are not implicated. ${ }^{106}$

Consider, for example, a recent study of auditors at major accounting firms who were given hypothetical accounting scenarios and asked to assess the accounting in each situation. ${ }^{107}$ Roughly half the accountants were asked to assume that they were retained by the firm they were auditing, while the rest were told to assume they had been hired by an outside investor who was considering making an investment in the company. ${ }^{108}$ In each scenario, the auditors were, on average, more likely to find that the company's financial reports complied with generally accepted accounting principles (GAAP) when they played the role of the company's accountant than when they were assigned to be the investor's accountant. ${ }^{109}$ The authors of the study reached the following conclusion:

Participants were placed in partisan roles that gave them a reason to desire a certain outcome. When asked then to make neutral judgments, they failed to extricate themselves from the influence of their partisan roles. It was as if, once they had arrived at a partisan perspective, the justifications for that perspective were readily accessible in their minds and so held undue sway over subsequent judgments, even when they were made in the presence of an explicit goal of impartiality. ${ }^{110}$

In sum, the accountants had the same objective task-to determine whether the financial statements complied with GAAP — but reached different conclusions depending on which client they had been randomly assigned to assist. ${ }^{111}$ The study suggests that partisanship itself is a situational force capable of distorting a professional's perceptions, including judgments relating to legal compliance.

105. See Kahneman, supra note 6, at 234-44 (reviewing studies showing that some experienced professionals are able to make accurate intuitive predictive judgments in certain situations). On the other hand, there is reason to question whether experienced lawyers are capable of making the kinds of predictive judgments that are necessary for sound intuitive decision making across a range of situations. See Goodman-Delahunty et al., supra note 99, at 133 (finding that "lawyers were overconfident in their [case outcome] predictions, and calibration did not increase with years of legal experience").

106. See infra notes 109 and 113 and accompanying text.

107. Moore, supra note 7.

108. Id. at 39 .

109. Id.

110. Id. at 46 (citation omitted).

111. Id.; see also Kaye J. Newberry, Philip M.J. Reckers \& Robert W. Wyndelts, An Examination of Tax Practitioner Decisions: The Role of Preparer Sanctions and Framing Effects Associated with Client Condition, 14 J. ECON. PsYCHOL. 439 (1993) (finding that accountants are more likely to sign a tax return containing a large deduction related to an ambiguous tax issue for an existing client than when the accountant is trying to obtain a new client). 
Several heuristics likely contribute to this effect. For example, as a result of the self-serving or confirmation bias, our recollection of information is "biased in favor of information that is consistent with the desired conclusions." 112 So when we are placed in partisan roles, we tend to filter information in ways that support that conclusion (i.e., the conclusion favoring our clients). This effect complicates our ability to make objective decisions, such as determining whether our clients are complying with existing legal requirements, as in the accountant study above.

This research implies not only that professionals, like everyone else, are susceptible to partisanship's distorting influence, but also that there is reason to believe that lawyers may be particularly vulnerable to this distortion given their institutional function. ${ }^{113}$ First, unlike the accountants in the above study, lawyers are supposed to make the best case for the client's position. That is, lawyers are supposed to take a partisan position, whereas the accountants in the study were not. Second, lawyers tend to perceive themselves as objective, which has the counterintuitive effect of making them less so. Research reveals that "telling people to be unbiased or highlighting their commitment to objectivity fails to reduce bias and may even exacerbate it." ${ }^{114}$ Because lawyers are trained to be objective, told that objectivity is a professional value, and praised for their objectivity, ${ }^{115}$ this training may have the counterintuitive effect of making lawyers less objective and less able to engage in an accurate assessment of new information. ${ }^{116}$

This effect is even stronger when people's sense of identity and self-worth is tied to their partisan stances. For example, one study revealed that an environmentalist whose self-worth is connected to the success of the environmental movement is less likely to acknowledge the validity of evidence showing a global disaster is not imminent. ${ }^{177}$ In contrast, an environmentalist is more likely to accept that evidence after receiving a self-affirmation unconnected to her role in the environmental movement. ${ }^{118}$

112. Linda Babcock \& George Loewenstein, Explaining Bargaining Impasse: The Role of Self-Serving Biases, 11 J. ECON. PERSP. 109, 114 (1997).

113. See Langevoort, Where Were the Lawyers?, supra note 75, at 104 (making a similar observation).

114. See Geoffrey L. Cohen, Identity, Belief, and Bias, in Ideology, Psychology, AND LAW 385, 392 (Jon Hanson ed., 2012) (citations omitted) (citing Charles G. Lord, Mark R. Lepper \& Elizabeth Preston, Considering the Opposite: A Corrective Strategy for Social Judgment, 47 J. Personality \& Soc. PSYCHOL. 1231 (1984); Eric Luis Uhlmann \& Geoffrey L. Cohen, "I Think It, Therefore It's True": Effects of Self-Perceived Objectivity on Hiring Discrimination, 104 Organizational Behav. \& Hum. Decision Processes 207 (2007)).

115. See Lawrence S. Krieger, Institutional Denial About the Dark Side of Law School, and Fresh Empirical Guidance for Constructively Breaking the Silence, 52 J. LEGAL EDUC. 112,125 (2002).

116. See Jonathon R. B. Halbesleben, M. Ronald Buckley \& Nicole D. Sauer, The Role of Pluralistic Ignorance in Perceptions of Unethical Behavior: An Investigation of Attorneys' and Students' Perceptions of Ethical Behavior, 14 Ethics \& BeHAv. 17, 25 (2004) (finding that lawyers tend to believe they have higher ethical standards than their peers).

117. See Anthony Bastardi \& Lee Ross, Maintaining Self-integrity: Effects of Threat to Personal Identity on Evidence Evaluation and Concession Making (2004) (unpublished manuscript on file with the Indiana Law Journal).

118. See id. 
Various studies have found that lawyers' identities and feelings of self-worth are particularly likely to be contingent on professional success. ${ }^{119}$ One scholar has found that "lawyers are tremendously prone to insecurity and an unhealthy need for status - a likely manifestation of the related law school paradigms around contingent self-esteem and comparative worth . . .."120 These findings imply that lawyers who have contingent self-esteem will have greater difficulty accurately assessing new information. Because their senses of self-esteem and identity are so intertwined with client-favorable outcomes, these lawyers may find it more difficult to assess information that tends to undermine their clients' positions.

Finally, we might expect lawyers to be more susceptible to bias than the subjects of the manufactured situations in the studies cited earlier. In real life, lawyers have even stronger incentives to please clients and help them achieve their goals because of the financial and professional benefits from doing so. Thus, there is little reason to believe that lawyers facing real world ethical issues are more capable of resisting the distorting effects of partisanship.

In sum, existing research suggests that partisanship may jeopardize a lawyer's ability to perceive a client's situation accurately, give sound advice, and provide ethically permissible representation. These dangers do not necessarily require a rejection of any particular theory of legal ethics. After all, whether a lawyer follows the dominant view or one of the alternatives, a lawyer still functions as a partisan. For example, even lawyers who are expressly committed to the pursuit of justice, such as prosecutors, are susceptible to the distorting effects of partisanship, as the scholarship relating to Brady disclosures indicates. ${ }^{121}$

The implications of this research should not be overstated. The studies do not show that lawyers' objectivity will be compromised in all situations or that partisanship is the most common reason for unethical behavior. ${ }^{122}$ Indeed, there is an ample and rich literature describing a wide range of reasons for lawyer misconduct and professional misconduct more generally. ${ }^{123}$ Conversely, most lawyers are capable of acting objectively and ethically in the vast majority of situations. The point is that existing theories overestimate professional objectivity and could be improved by incorporating a more realistic understanding of lawyer behavior.

119. See, e.g., Krieger, supra note 115, at 119.

120. Id.

121. See supra note 4.

122. See Langevoort, Where Were the Lawyers?, supra note 75, at 110 (contending that, "we have no way of knowing how frequently the behavioral explanation [for unethical behavior] is the best one"). Indeed, there are many causes of unethical behavior. See Francesca Gino, Shahar Ayal \& Dan Ariely, Contagion and Differentiation in Unethical Behavior: The Effect of One Bad Apple on the Barrel, 20 Psychol. Sci. 393 (2009). See generally Owen Flanagan, Varieties of Moral Personality: Ethics and Psychological Realism (1991).

123. See Linda K. Treviño, Gary R. Weaver \& Scott J. Reynolds, Behavioral Ethics in Organizations: A Review, 32 J. MGMT. 951 (2006) (offering an overview of social science literature on ethics in various organizational settings). 


\section{REVISITING THE OBJECTIVE-PARTISAN ASSUMPTION IN LEGAL ETHICS THEORY}

Thus far, this Article suggests that the leading theories of legal ethics have unexamined weaknesses that could be addressed by accounting for the ways in which partisanship distorts lawyers' objectivity. Incorporating these behavioral insights can benefit legal ethics theories in much the same way as those insights have improved neoclassical economics. Part III.A explores the analogy to behavioral economics and identifies some possible objections to it. Part III.B then explains where behavioral insights are most needed and concludes that they are particularly valuable when lawyers encounter factual or legal ambiguities.

\section{A. An Analogy to Behavioral Economics}

Behavioral economists emphasize that they seek to supplement- - not replaceneoclassical economics. ${ }^{124}$ Neoclassical economists traditionally assume that people are rational, self-interested actors. ${ }^{125}$ Behavioral economists have shown that human conduct varies in predictable ways from this assumed model and that, by understanding these variations, it is possible to develop more accurate and useful economic theories and policies. ${ }^{126}$

In much the same way, a behavioral theory of legal ethics is neither a rejection nor an endorsement of any particular theory of legal ethics. Rather, a behavioral theory of legal ethics is premised on the idea that lawyer behavior is not as objective or rational as theorists typically assume. By understanding why lawyers' behavior varies in this way (e.g., by understanding when and how partisanship distorts a lawyer's perceptions), legal ethics theories can offer more accurate and useful prescriptions.

This analogy to behavioral economics is not perfect. Neoclassical economics offers a descriptive model of human behavior, and its descriptive power can be enhanced through the incorporation of behavioral insights. ${ }^{127}$ In contrast, legal ethics theories are essentially normative - they tell lawyers how they should behave rather than describing how they $d o$ behave. Because these normative theories do not purport to describe lawyer behavior, they do not benefit from social science research on human behavior in the same way as neoclassical economics.

That said, behavioral research can inform and improve normative theories. Consider normative theories of economics, such as libertarianism, ${ }^{128}$ socialism, ${ }^{129}$ or the range of economic theories in between. Each of these theories contains normative rather than merely descriptive theories of economics, yet they all benefit from behavioral insights. For instance, socialism can be (and has been) critiqued on the grounds that it relies on

124. See Dan Ariely, Predictably Irrational: The Hidden Forces That Shape Our DeCisions 43-48 (rev. \& expanded ed. 2009).

125. See E. Roy Weintraub, Neoclassical Economics, LiBR. ECON. \& LiBERTY, http://www.econlib.org/library/Enc1/NeoclassicalEconomics.html.

126. See ARIELY, supra note 124, at 43-48.

127. See generally KAHNEMAN, supra note 6 .

128. See, e.g., Milton Friedman \& Rose Friedman, Free to Choose: A Personal STATEMENT (1980).

129. See, e.g., Karl Marx \& Friedrich Engels, The Communist Manifesto (1848). 
an unrealistic vision of how human beings behave. ${ }^{130}$ Similarly, it has been suggested that libertarianism can benefit from behavioral research through the development of policies that retain freedom of choice but "influence choices in a way that will make choosers better off, as judged by themselves." 131 Although this notion of "soft paternalism" 132 is controversial, the point of these examples is that both descriptive and normative theories can benefit from behavioral research.

Similarly, numerous legal theories have benefited from behavioral insights. For example, conventional theories of tort law prescribe a set of background principles and prescriptions for human behavior in particular contexts, and legal scholars have shown that social science insights can improve these conventional concepts. ${ }^{133}$ Put another way, scholars increasingly have found that social psychology helpfully informs foundational theories in many areas of law. ${ }^{134}$ Legal ethics should not be an exception.

Another analogy from a completely different context can help to explain why ethics theories could benefit from behavioral science. Consider an archer whose objective is to hit a target. This goal is easily understandable (the archer should try to hit the center of the target), but that goal cannot be regularly achieved without understanding how extrinsic forces, such as wind or distance, might affect the trajectory of the archer's arrow. Any useful set of prescriptions for archers cannot simply say: "You should hit the center of the target." The archer needs to be told how to do so, including how to adjust her aim to account for the range of forces that affect her accuracy.

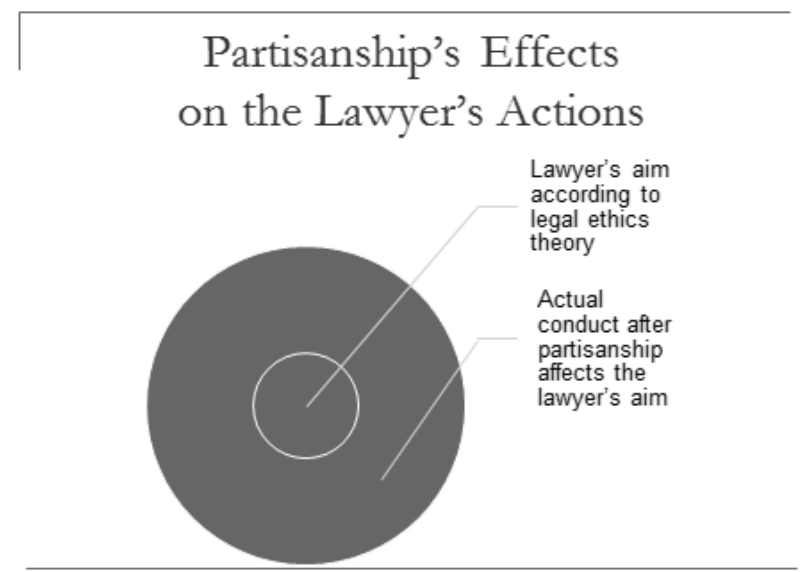

Figure 2. Partisanship's Distorting Influence.

130. See John Kenneth Galbraith, The Good Society: The Humane Agenda 59-60 (1996)

131. Richard H. Thaler \& Cass R. Sunstein, Nudge: Improving Decisions About Health, Wealth, AND Happiness 5 (2008) (emphasis omitted).

132. Cass Sunstein, Libertarian Paternalism, U. ChI. L. SCH. FaC. Blog (Jan. 20, 2007, 10:40 AM), http://uchicagolaw.typepad.com/faculty/2007/01/libertarian_pat.html.

133. See Jon Hanson \& Michael McCann, Situationist Torts, 41 Loy. L.A. L. REv. 1345 (2008).

134. See generally IdeOlOGY, Psychology, AND LAw, supra note 19. 
In much the same way, theorists cannot simply instruct lawyers to pursue justice, a conception of morality, or a client's legal entitlements and expect lawyers to hit their targets. Lawyers also must be told how to hit those targets in light of what we know about the ways in which forces, such as partisanship, distort the lawyer's aim. A behavioral theory of legal ethics offers this additional guidance and provides a critical, but largely unexamined, method for improving existing theories.

\section{B. Legal Ethics Theory and the Problem of Ambiguity}

Before turning to the question of how theorists might adjust their prescriptions to account for situational forces such as partisanship, it is useful to understand when these situational forces are most likely to distort a lawyer's perception (i.e., when a lawyer's "aim" is most likely to be affected).

Consider the following examples:

(1) A lawyer is representing the seller of a business and must disclose various financial figures to the prospective buyer. The lawyer for the seller begins to question the authenticity of the client's financial figures but is not certain that the numbers are actually false. ${ }^{135}$

(2) A lawyer must decide whether an important document is responsive to a particular document request. The discoverability of the document is debatable because the law does not clearly resolve how broadly to interpret the document request. ${ }^{136}$

(3) A prosecutor who is seeking to convict someone for committing a heinous crime comes across arguably exculpatory evidence the defense does not have. ${ }^{137}$

In each of these cases, the truth is difficult to discern, either because the facts are unclear (such as in the case of the financial figures) or the law is unclear (such as determining whether particular information is discoverable or exculpatory). These situations require the kinds of judgments that, when viewed through the lens of partisanship, increase the likelihood that a lawyer will overestimate the accuracy of the client's information or the strength of the client's legal position. In these contexts, social science suggests that lawyers will have more difficulty making the kinds of objective decisions existing theories assume. ${ }^{138}$ For example, studies suggest that lawyers are willing to engage in impermissible negotiation tactics because of

135. Cf. Heidi Li Feldman, Codes and Virtues: Can Good Lawyers Be Good Ethical Deliberators?, 69 S. CAL. L. REV. 885, 916-24 (1996) (providing an overview of fraudulent loans in the O.P.M. case); Hinshaw \& Alberts, supra note 18.

136. See Washington State Physicians Ins. Exch. \& Ass'n v. Fisons Corp., 858 P.2d 1054 (Wash. 1993).

137. See Kyles v. Whitley, 514 U.S. 419 (1995).

138. See Francesca Gino \& Max H. Bazerman, When Misconduct Goes Unnoticed: The Acceptability of Gradual Erosion in Others' Unethical Behavior, 45 J. EXPERIMENTAL Soc. PSYCHOL. 708, 710 (2009) (noting that unethicality is more difficult to identify in ambiguous situations). 
ambiguities in the law, ${ }^{139}$ and ample evidence exists that lawyers regularly make cognitive mistakes in the third situation above. ${ }^{140}$

In contrast, partisanship poses less of a problem when the law or the facts are easily discernible. For example, imagine a lawyer receives a document that was sent by mistake from opposing counsel and must decide whether to take advantage of that mistake. Rule 4.4(b) of the Model Rules of Professional Conduct gives the lawyer discretion to look at the document, so there is no ambiguity in that regard. ${ }^{141}$ Moreover, there is no debate about the facts - the document was sent to the lawyer by mistake. Because the facts and the law are clear, existing theories can be applied as intended. For example, the dominant view would suggest that, assuming the client wants the lawyer to look at the document, the lawyer should do so. Partisanship is less likely to cause the lawyer to engage in impermissible conduct under these circumstances.

Other situations may involve legal issues or factual questions that are neither ambiguous (as in the three examples above) nor clearly resolved (as in the case of the inadvertently sent document). Rather, the legal issues or factual questions may strongly, but inconclusively, favor a particular view. In these situations, partisanship may have a distorting effect, but not as strong as when the law or the facts are more genuinely in doubt. In other words, many (if not most) factual and legal issues are neither clear nor unclear; they lie somewhere in between. The point is that partisanship is more likely to have a distorting effect as the ambiguity of a legal or factual question increases. Or, to use the archer metaphor, partisanship is most likely to affect the lawyer's aim and ability to hit a target when the facts or law are unclear.

Existing theories fail to account for this effect. Consider, for example, the dominant view. Lawyers who adopt it are supposed to pursue a client's interests to the full extent the law allows and must therefore determine what the law actually permits. The research on partisanship suggests that a lawyer will have difficulty making this determination objectively, especially when the determination turns on ambiguous facts or unclear propositions of law, as in the examples above. The result is that lawyers in these kinds of situations will be more likely to make mistakes when determining what is lawful, thus increasing the risk of crossing the line between permissible and impermissible behavior.

One might think that this problem is one to be solved by rule makers rather than dominant-view theorists. After all, if we know that lawyers are going to misinterpret the location of the line between permissible and impermissible advocacy, the rules might be drafted more strictly to ensure that lawyers steer clear of the behavior that is of greatest concern. The problem with this solution is that cognitive biases do not affect all lawyers the same way. Moreover, some ethical issues may be ambiguous in some situations (say, where the facts are unclear) but quite clear in others. As a result, overly strict drafting would unnecessarily deter legitimate conduct. This problem, therefore, is not one that can be neatly solved through creative rule drafting.

139. See Hinshaw \& Alberts, supra note 18 (suggesting that ambiguities in law encourage lawyers to engage in impermissible negotiation tactics).

140. See Heath \& McCoy, supra note 4 (showing that prosecutors make cognitive mistakes when determining whether particular evidence is exculpatory).

141. See ABA Comm. on Ethics \& Prof'l Responsibility, Formal Op. 437 (2005) (discussing Rule 4.4(b) of the Model Rules of Professional Conduct). 
Dominant-view critiques suffer from similar problems. For example, as explained earlier, William Simon believes that "[t]he lawyer should take those actions that, considering the relevant circumstances of the particular case, seem most likely to promote justice." 142 David Luban has criticized Simon for prescribing an unrealistically complicated analysis of whether a client's position is just. ${ }^{143}$ Simon replies that such an analysis is not as complicated as Luban suggests. ${ }^{144}$ This intramural debate over the complexity of the analysis overlooks an even more fundamental problem: even if lawyers are able to undertake the kind of analysis that Simon prescribes, lawyers are not necessarily able to do so reliably in the context of a particular representation. The reality is that lawyers who encounter legal or factual ambiguities of the sort described above are more likely to misjudge what constitutes a just course of action than Simon's theory assumes.

These errors of judgment can be as problematic as those made by lawyers operating under the dominant view. For example, prosecutors seek to achieve justice, but their partisan role can infect their decision making and cause them to withhold exculpatory information that they are constitutionally and ethically obligated to disclose.

Luban's approach suffers from the same kind of problem. He proposes that lawyers should pursue morally worthy ends using morally justifiable means. ${ }^{145}$ The problem is that, even if moral calculations are easier to make than Simon's sophisticated judgments about justice, there is no reason to believe that moral judgments are any more immune from partisanship's distorting influence than the kinds of judgments Simon recommends. Lawyers who are asked to make moral judgments in the context of legal or factual ambiguities will have more difficulty doing so than Luban's theory assumes and can make the same kinds of mistakes as lawyers who are committed to the dominant view or Simon's position. ${ }^{146}$

This discussion suggests that legal ethics theories should not prescribe a one-size-fits-all approach to lawyer conduct (e.g., instructing lawyers to pursue a client's interests, well-grounded legal entitlements, the interests of justice, some sense of morality, etc.) Rather, as explained below, prescriptions need to vary depending on the ambiguity of the law and facts involved.

\section{TOWARDS A BEHAVIORAL THEORY OF LEGAL ETHICS}

To this point, this Article has suggested that theorists' reliance on the objective-partisan assumption is problematic, particularly when lawyers face factual or legal ambiguities. This Part identifies several ways in which existing theories could be refined to reflect this reality, such as prescribing more context-dependent

142. Simon, supra note 42, at 1090.

143. David Luban, Reason and Passion in Legal Ethics, 51 STAN. L. REV. 873, 893-901 (1999).

144. William H. Simon, The Legal and the Ethical in Legal Ethics: A Brief Rejoinder to Comments on The Practice of Justice, 51 Stan L. Rev. 991, 995 (1999).

145. See LUBAN, supra note 2, at Xxii.

146. See Ann E. Tenbrunsel \& David M. Messick, Ethical Fading: The Role of Self-Deception in Unethical Behavior, 17 Soc. Just. RES. 223 (2004) (finding that people have a tendency to act self-interestedly while simultaneously believing that their moral principles are upheld). 
behavior, advocating for revisions to certain features of the law of lawyering, and encouraging changes to legal education.

\section{A. Context-Dependent Prescriptions and the Importance of Debiasing}

Legal ethics theories tend to offer a single, unvarying prescription for lawyer behavior. These prescriptions, however, fail to account for the ways in which a theory may be misapplied in light of partisanship's distorting influence. ${ }^{147}$

Theories of legal ethics can - and should - account for these distortions through more context-dependent prescriptions. ${ }^{148}$ For instance, rather than prescribing the same conduct in every situation (e.g., pursuing the client's interests to the full extent the law allows), theorists should acknowledge that lawyers need to adopt a different mindset when they are faced with ambiguous legal and factual questions, such as those described earlier. ${ }^{149}$ In these situations, theorists should prescribe debiasing techniques that reduce cognitive biases and increase the likelihood that lawyers can make more objective and effective decisions. ${ }^{150}$ Debiasing strategies could include, for example, seeking second opinions from more objective observers, ${ }^{151}$ or explicitly writing out the counterarguments to a position.

The prescription to seek second opinions is particularly attractive because existing structures exist to facilitate it. Large firms have general counsel or ethics committees that can address ethics-related questions. Similarly, most bar associations have free ethics hotlines to answer questions from solo practitioners and lawyers at smaller firms. By encouraging lawyers to get these kinds of second opinions in situations where cognitive biases are most likely to occur, theorists can increase the likelihood that their prescriptions will be applied in the manner intended. ${ }^{152}$

Debiasing strategies, though useful, are not panaceas. One important problem is that lawyers sometimes have difficulty identifying situations that implicate ethical

147. Cf. Woolley \& Wendel, supra note 20, at 1066-69 (observing that existing theories tend to treat all lawyers the same way and arguing that the theories need to account for differences in personality traits).

148. See Ted Schneyer, Moral Philosophy's Standard Misconception of Legal Ethics, 1984 Wis. L. REV. 1529 (1984).

149. See supra text accompanying notes 135-37.

150. See Ian Weinstein, Don't Believe Everything You Think: Cognitive Bias in Legal Decision Making, 9 CLINICAL L. REV. 783 (2003) (exploring the impact of cognitive bias on both lawyers and clients and suggesting how to identify and mitigate these biases).

151. See Jennifer Gerarda Brown, Addressing Partisan Perceptions, in Rethinking Negotiation Teaching: Innovations for Context and Culture 115, 116 (Christopher Honeyman, James Coben \& Giuseppe De Palo eds., 2009) ("When partisan perceptions are impeding dispute resolution, third party intervention is often necessary. This is because it can be difficult for the parties to see that their perceptions are skewed."); Hazard, supra note 14, at 247; see also Linda Babcock, George Loewenstein \& Samuel Issacharoff, Creating Convergence: Debiasing Biased Litigants, 22 LAW \& Soc. INQUIRY 913 (1997) (finding lawyers less biased about their cases when forced to articulate the other side's position).

152. But see Richard L. Abel, LAWyers in the Dock: LEARNING From AtTORNey DisciplinARY PROCEEDINGS 389-403 (2008) (noting a case where a lawyer sought a second opinion from someone who also had a vested interest in the outcome). 
concerns - a problem known as "ethical fading." 153 This "fading" occurs for a variety of reasons, including groupthink, optimism bias, deference to authority figures, and the gradual nature in which many ethical problems arise. ${ }^{154}$ It is also difficult to educate people about cognitive distortions because of "blind spot bias," a bias about our own resistance to bias. ${ }^{155}$ For these and other reasons, debiasing techniques, such as encouraging lawyers to seek second opinions in appropriate cases, will not always be effective. Nevertheless, by identifying the problem of bias and suggesting useful (albeit not foolproof) solutions, scholars can improve ethics theories through more realistic prescriptions for lawyer behavior.

These context-specific prescriptions for debiasing may seem divorced from the conceptual world of legal ethics theories, but those theories are only useful insofar as they reflect the way lawyers actually behave in practice. By acknowledging that lawyers are susceptible to cognitive biases in certain situations and offering contextdependent remedies, theorists can develop more complete, normatively attractive, and empirically justifiable prescriptions for lawyers to follow.

\section{B. Debiasing Through Substantive Law}

Another promising strategy for minimizing the effects of cognitive bias is to develop laws, rules, or legal frameworks to help prevent biased decision making. ${ }^{156}$ This strategy of "debiasing through substantive law" is premised on the idea that it may offer a less intrusive way to address bounded rationality than flatly prohibiting certain choices from being made. ${ }^{157}$ For example, Professors Christine Jolls and Cass Sunstein argue for increasing the percentage of outside directors on corporate boards because those directors are less susceptible to cognitive bias. ${ }^{158}$ This approach is less intrusive than, say, restricting or regulating a board's choices and can have a similarly positive effect. This concept of debiasing through substantive law has several possible implications for the law governing lawyers, including the increased use of law firm discipline and proactive entity regulations.

153. Tenbrunsel \& Messick, supra note 146; see also Langevoort, Where Were the Lawyers? supra note 75, at 113-14 (noting that lawyers have blind spots, particularly in light of the structures of modern law firms).

154. Langevoort, supra note 18, at 509-11.

155. See Emily Pronin, Daniel Y. Lin \& Lee Ross, The Bias Blind Spot: Perceptions of Bias in Self Versus Others, 28 Personality And Soc. Psychol. Bull. 369 (2002); cf. Babcock et al., supra note 151, at 916 ("Another commonly discussed bias is overconfidence, which refers to the tendency . . . to display inflated confidence in their judgments . . .." (emphasis in original)).

156. See Christine Jolls \& Cass R. Sunstein, Debiasing Through Law, 35 J. Legal Stud. 199, 200-01 (2006) (explaining that "debiasing through law will often be a less intrusive, more direct, and more democratic response to the problem of bounded rationality").

157. Id. at 206 .

158. Id. at 217 ("Of particular relevance for our purposes is the idea that such directors may help to overcome various biased judgments on the part of inside directors. For instance, inside directors may fall prey to optimism bias in predicting corporate outcomes." (citations omitted)). 


\section{Law Firm Discipline}

The Model Rules of Professional Conduct currently focus primarily, if not exclusively, on the behavior of individual lawyers rather than the firms where those lawyers work. ${ }^{159}$ Professor Ted Schneyer and others have argued that this lawyer-based system of regulation could be usefully supplemented by a set of disciplinary rules designed to regulate firms themselves. ${ }^{160} \mathrm{~A}$ couple of U.S. jurisdictions (New York and New Jersey) have adopted a variant of this idea by imposing supervisory responsibility on firms themselves and not just specific lawyers. ${ }^{161}$

One powerful argument for firm-based discipline is that it is sometimes difficult to blame misconduct on any particular lawyer or group of lawyers. For example, the cause of misconduct may be inadequate processes and procedures within the firm. ${ }^{162}$ Law firm discipline, such as public reprimands or monetary sanctions, can provide a mechanism for holding firms accountable in these situations, thus incentivizing firms to create more effective structures for ensuring appropriate conduct. ${ }^{163}$

A behavioral approach to legal ethics suggests a reason to endorse firm-based discipline that has not been previously explored: the structures and systems that would insulate the firm against firm-based discipline also might help to protect lawyers against cognitive distortions, such as those produced by partisanship.

A rigorous system of firm-based discipline might incentivize firms to create procedures that minimize the likelihood of cognitive errors. For example, firms might ask their own lawyers to conduct case or project audits of colleagues. These audits might involve a periodic review of a team's decisions by a non-team lawyer. This lawyer-auditor could be instructed to discuss questionable legal and factual issues that the team has encountered or inquire about possible ethical dilemmas the team failed to raise on its own initiative or failed to see because of ethical fading. ${ }^{164}$

159. See Ted Schneyer, The Case for Proactive Management-Based Regulation to Improve Professional Self-Regulation for U.S. Lawyers, 42 HoFSTRA L. REV. 233 (2013).

160. See generally Adam M. Dodek, Regulating Law Firms in Canada, 90 CANADIAN B. REV. 383 (2011); Ted Schneyer, Professional Discipline for Law Firms?, 77 CORNELL L. ReV. 1 (1991).

161. Elizabeth Chambliss \& David B. Wilkins, A New Framework for Law Firm Discipline, 16 Geo. J. Legal Ethics 335, 340 n.34 (2003) (citing New Jersey and New York rules). "The New Jersey rule ... requires law firms to make 'reasonable efforts to ensure that member lawyers . . . undertake measures giving reasonable assurance that all lawyers conform to the Rules of Professional Conduct."” Id. (citing N.J. R. of Prof'L ConduCt R. 5.1(a) (1984)). “The New York rule, adopted in 1996, requires law firms to 'make reasonable efforts to ensure that all lawyers in the firm conform to the disciplinary rules." Id. (citing N.Y. R. OF PROF'L CONDUCT R 5.1(a) (originally enacted as N.Y. CODE OF Prof'L RESPONSIBILITY DR 1-104 (1996))).

162. See Mass. Bd. of Bar Overseers, Admonition No. 08-11, MASs.GOv, http://www.mass.gov /obcbbo/admon2008.htm (finding failures in a large law firm's conflicts detection system and noting that "firm discipline" was not an option in Massachusetts).

163. See Chambliss \& Wilkins, supra note 161, at 335-36 (citing Schneyer, supra 160, at 35) ("[S]ome types of collective sanctions, such as public censure or shaming, may be more effective against law firms than business corporations, because law firms belong to a 'reasonably well-defined ethical community."').

164. Of course, other reasons exist, such as an unwillingness to alienate team members or a concern that the inquiry may bring an unwelcome answer. Again, an audit is not a panacea, 
Such audits might help to identify problematic decisions, offer useful feedback, and (most critically) protect long-term members of a team from biased decisions by introducing an outsider's fresh perspective.

Of course, firms could try audits or other debiasing strategies today without a regime of law firm discipline. The point here is that law firm discipline might incentivize the creation of structures that help to reduce the distorting effects of serving in a partisan role.

As with other strategies, this approach is not a perfect solution. After all, law firms already have an incentive to prevent ethical violations because of potential malpractice liability. ${ }^{165}$ Law firm discipline, however, will create incentives to guard against ethical problems that might not otherwise give rise to liability. With a realistic threat of firm-based discipline, law firms will have a reputational incentive to develop new and innovative structures that can more effectively prevent biased decision making among lawyers in the firm. ${ }^{166}$ In other words, the substantive law of lawyering can be used to incentivize firms to develop improved debiasing strategies.

\section{Proactive Regulation}

Another possible prescription is proactive regulation. Currently, the U.S. system of lawyer regulation is largely reactive in the sense that lawyers interact with it only when they are the subject of a complaint. In contrast, a system of proactive regulation includes ex ante regulations that help to prevent ethical violations and malpractice claims from occurring in the first place. ${ }^{167}$ For example, one modest way in which the United States is proactive is through mandatory continuing legal education requirements, which are intended to ensure that lawyers maintain a minimum level of competence.

More elaborate mechanisms are possible, such as conducting routine audits of firms to determine whether they have appropriate procedures in place regarding the timely "provision of services, avoidance of careless errors, adequate documentation of fee terms and billing, timely recognition and resolution of conflicts of interest, sound records management, adequate supervision of practitioners and staff, and prevention of trust account violations." 168 This kind of system can be found in other parts of the world, such as England and New South Wales, and evidence suggests that these systems may reduce ethics complaints and malpractice claims. ${ }^{169}$

particularly given the cost and time involved, but it can help to address aspects of ethical fading.

165. See Julie Rose O'Sullivan, Professional Discipline for Law Firms? A Response to Professor Schneyer's Proposal, 16 GeO. J. Legal Ethics 1, 29 (2002).

166. See Chambliss \& Wilkins, supra note 161, at 335-36.

167. Schneyer, supra note 159.

168. Ted Schneyer, Thoughts on the Compatibility of Recent U.K. and Australian Reforms with U.S. Traditions in Regulating Law Practice, 2009 J. Prof. LAw. 13, 32.

169. See Christine Parker, Tahlia Gordon \& Steve Mark, Regulating Law Firm Ethics Management: An Empirical Assessment of an Innovation in Regulation of the Legal Profession in New South Wales, 37 J. L. \& Soc. 466 (2010) (Eng.); Steve Mark, Views from an Australian Regulator, 2009 J. Prof. LAW. 45 (2009); Schneyer, supra note 160, at 27-37; see also John Briton \& Scott McLean, Incorporated Legal Practices: Dragging the Regulation of the Legal 
Behavioral research may help to explain why proactive regulations are effective. These regulations increase the likelihood that firms will have appropriate oversight mechanisms, such as policies regarding the supervision of lawyers and staff, that reduce biased decision making. Again, as with law firm discipline, proactive regulation cannot prevent all ethical problems, but it can foster the creation of more robust internal regulatory structures that may debias the relevant decision makers and reduce the likelihood of inappropriate conduct.

\section{The Role of Discretion in Professional Rulemaking}

Flaws in the objective-partisan assumption also have implications for the structure of the profession's ethics rules as well as the content of related policies. Regarding the structure of the rules, one important debate among legal ethicists is whether lawyers should be subject to law-like rules, such as those found in the Model Rules of Professional Conduct, or be afforded more discretion in the exercise of their professional duties. ${ }^{170}$ For example, Professor William Simon has contended that lawyers should have more discretion to make ethical judgments than the Model Rules of Professional Conduct currently allow. ${ }^{171}$

The problem with the discretionary approach is that it assumes lawyers employ their discretion in a manner that is consistent with theorists' prescriptions. As this Article makes clear, such an assumption is flawed, particularly when lawyers encounter ethics-related issues involving legal or factual ambiguities. ${ }^{172}$ If the rules offer more discretion, the law of lawyering will be even more ambiguous, increasing the likelihood that various cognitive distortions will impact lawyers' behavior. In sum, a behavioral theory of legal ethics has implications for theorists' views on the structure of lawyer regulation and suggests that the movement towards law-like rules will enhance, rather than detract from, lawyers' ability to act in ways that are consistent with the principles that scholars propose.

For related reasons, a behavioral theory of legal ethics suggests that rules and policies could be revised to eliminate discretion in contexts where there is a particularly high likelihood of cognitive error. For example, prosecutors regularly err

Profession into the Modern Era, 11 Legal Ethics 241 (2008) (Eng.) (discussing Queensland's similar program). More recently, the ABA Commission on Ethics 20/20 considered proactive entity regulation. See Memorandum from Jamie S. Gorelick \& Michael Traynor, Co-Chairs, ABA Comm'n on Ethics, to ABA Entities, Courts, Bar Associations, Law Schools, and Individuals (Dec. 28, 2011), available at http://www.americanbar.org /content/dam/aba/administrative/ethics_2020/20111228_summary_of_ethics_20_20_commis sion_actions_december_2011_final.authcheckdam.pdf. The Commission considered the idea sufficiently worthy of future study that the issue was referred to the ABA Standing Committee on Professional Discipline. See id. at 9.

170. See Simon, supra note 42; see also Samuel J. Levine, Taking Ethical Discretion Seriously: Ethical Deliberation as Ethical Obligation, 37 IND. L. REV. 21 (2003); Fred C. Zacharias, Reconciling Professionalism and Client Interests, 36 WM. \& MARY L. REV. 1303, 1353-70 (1995).

171. See Simon, supra note 42.

172. See Robert W. Gordon, The Radical Conservatism of The Practice of Justice, 51 STAN. L. REV. 919, 928 (1999) (criticizing Simon's approach on this ground). 
when making case-by-case determinations about what must be disclosed to the accused under Brady v. Maryland. ${ }^{173}$ This type of cognitive error can be reduced with an "open file" policy. ${ }^{174}$ Such a policy gives the accused access to all information in the prosecutor's file, not just the information an individual prosecutor deems exculpatory. Some prosecutors' offices have experimented with this approach, and it has received significant attention among scholars and the popular press. ${ }^{175}$ Although it is not a panacea, ${ }^{176}$ this approach reflects the kind of practical prescription that ensures greater compliance with existing theories of legal ethics.

\section{Teaching Cognitive Bias in Legal Education}

A final way to ensure that ethics theories are applied in the manner scholars intend is to educate law students and lawyers about cognitive bias. Although the previously mentioned blind spot bias makes this effort difficult, there are several promising approaches. One social psychologist has found that, by making people more aware of their own lack of objectivity, they can assess new information more accurately. ${ }^{177}$ This awareness is particularly effective when people are told about specific individuals who have made mistakes due to cognitive errors rather than merely being exposed to statistics about cognitive bias. ${ }^{178}$ There is also evidence that people are less susceptible to partisanship's effects if their identities and senses of self-worth are not contingent on the outcome of a partisan fight. ${ }^{179}$

These findings suggest that some reforms to legal education might minimize partisanship's effects on judgment. For example, law schools could expose students to social science research on objectivity and impartiality to help counter the mythology of the lawyer as an objective partisan. Students could also be exposed to the stories of specific well-regarded lawyers who engaged in ethical misconduct. ${ }^{180}$ This type of instruction could occur in first year lawyering classes, professional responsibility courses, clinics, and any other setting where lawyering skills and values are taught. This type of education will not provide complete immunization against partisanship's infecting influence, but it can increase the likelihood that lawyers will recognize the limits of their own objectivity, employ debiasing strategies, and make better decisions.

173. 373 U.S. 83 (1963); see supra note 4.

174. Yaroshefsky, supra note 17, at 1330.

175. See id. (arguing that broader disclosure obligations help to offset cognitive biases among prosecutors); Editorial, Justice and Open Files, N.Y. TIMES, Feb. 27, 2012, at A18.

176. See, e.g., Joel Cohen \& Danielle Alfonzo Walsman, The 'Brady Dump': Problems with 'Open File' Discovery, N.Y. L.J., Sept. 4, 2009, available at http://www.stroock.com /SiteFiles/Pub829.pdf.

177. See Uhlmann \& Cohen, supra note 114, at 207.

178. See KAHNEMAN, supra note 6, at 174.

179. See Geoffrey L. Cohen, Joshua Aronson \& Claude M. Steele, When Beliefs Yield to Evidence: Reducing Biased Evaluation by Affirming the Self, 26 PERSONAlity \& Soc. PSYCHOL. BULL. 1151 (2000).

180. For example, many professors ask disbarred lawyers to speak about their experiences with students. Another option is to assign books and articles that explain why successful lawyers have been disbarred or disciplined. 
Another option would be for legal educators to help students develop a stronger sense of self-worth that is independent of professional and financial success. ${ }^{181}$ Some ideas include reducing reliance on the strict Socratic method (i.e., reducing methods that are likely to embarrass or intimidate students), actively encouraging students to seek out rewarding work instead of the highest paid work, developing less demeaning grading curves, ${ }^{182}$ and urging students to retain their moral intuitions instead of only engaging in the relativism-promoting exercise of seeing the other side of every legal argument. ${ }^{183}$

Yet another option is to teach professional responsibility through simulation exercises rather than through the more traditional discussion of cases and hypotheticals. By placing students in realistic situations where they have to resolve an ethical issue presented to them, they are more likely to learn how to identify similar types of problems in practice.

Again, educating people about cognitive distortions does not automatically produce objective partisans. After all, even if we know that the image of the tables earlier in this Article is fooling us, it is difficult to see the tables as the same size. ${ }^{184}$ For conceptually similar reasons, we have trouble identifying when we are subject to ethical fading even when we are familiar with the concept. Nevertheless, the studies described above suggest it may be possible to increase the likelihood that lawyers will identify ethics issues accurately when they arise, just as we can learn to recognize that a two-dimensional object depicted as a three-dimensional object can cause us to misperceive its size. At the very least, theorists should consider how pedagogy might ensure greater fidelity to the models of lawyer behavior that they propose.

\section{CONCLUSION}

Behavioral insights have informed many areas of law, including the field of professional responsibility. ${ }^{185}$ Those insights, however, have had only a modest effect on the foundational theories of legal ethics, even though those theories are, at their core, prescriptions about human behavior. The reality is that lawyers' conduct cannot be understood, theorized about, or used to produce the best possible regulations without an appreciation for the limits on human rationality and objectivity. A behavioral theory of legal ethics offers a way to incorporate those realties into the foundational debates on a lawyer's professional role so that scholars can produce more useful, normatively appealing, and empirically justifiable models for lawyer conduct, regulation, and education.

181. Kennon M. Sheldon \& Lawrence S. Krieger, Does Legal Education Have Undermining Effects on Law Students? Evaluating Changes in Motivation, Values, and Well-Being, 22 BEHAV. SCI. \& L. 261, 275-76 (2004) (demonstrating the effects of legal education on law students' self-worth).

182. Joshua M. Silverstein, A Case for Grade Inflation in Legal Education, 47 U.S.F. L. REV. 487 (2013).

183. See Krieger, supra note 115; Andrew M. Perlman, Remedying Law's Partiality Through Social Science, in IdeOlogy, Psychology, AND Law 404 (Jon Hanson ed., 2012).

184. In fact, cognitive illusions may be more difficult to address than visual illusions. KAHNEMAN, supra note 6, at 216-17.

185. See supra note 18 and accompanying text. 
